\title{
Non-Parametric Analysis of Land Function Misuse in Kalibawang and Samigaluh Subdistrict
}

\author{
$1^{\text {st }}$ Ani Apriani ${ }^{1}, 2^{\text {nd }}$ Bayurohman Pangacella Putra ${ }^{2}$ \\ aniapriani@itny.ac.id ${ }^{1}, \underline{\text { bayurohman@itny.ac.id }}^{2}$ \\ ${ }^{1,2}$ Institut Teknologi Nasional Yogyakarta, Indonesia
}

\begin{abstract}
The increase in population resulted in the large area of land used as residential areas. Whereas, Indonesia has diverse topographic features including mountains, hills and plains. Therefore it is necessary to divide the functions of the area starting from the protected, buffer zone, annual crop cultivation, and cultivation and settlement functions area. Each function of the area has criteria and should stand on their respective functions. The purpose of this study is to find out how much the land is used differently from its geographical function in Kalibawang and Samigaluh Subdistricts. Another goal is to compare the land conversion in these two locations. The study is carried out by taking geomorphological data in both subdistricts. Furthermore, with a descriptive quantitative approach and comparative test (Man Witney), the comparison of land use in these two locations can be seen. The results of the analysis show that more land conversion occurs in Samigaluh District compared to Kalibawang District. This is indicated by the conversion of land in Samigaluh Subdistrict reaching $48 \%$ of its area, meanwhile the land conversion in Kalibawang Subdistrict is $32 \%$. Non-parametric comparative test says that land use conversion in these sub-districts is quite significant.
\end{abstract}

Keyword: Land Function, geomorphological, cultivation

\section{Introduction}

Indonesia lies on tectonic subduction zone. This makes volcanoes, intrusions, faults, and folds constitute indonesia's diver morphology. Montainous area has high risk assiciated to land slide and land slide occurence will increase at rainy season because of land geotechnical properties alteration by rain water[1].

One of Provinces in Indonesia that has various morphology condition is D.I. Yogyakarta. Tophological variety in this area makes it high in resources as well as geological risks. Mistakes in resources management lead to disasters, eventhough other factor such as geological aspect also plays part. Disasters that often occure in D.I. Yogyakarta are water overflow, land failure, drought, wildfire, earthquake, and storm [2]. According to BNPB up to November 2016, land slide occurence in D.I. Yogyakarta is ranked first overall in Indonesia with 83 cases, followed by water overflow by 67 cases [3].

Menoreh Hills area, i.e. Girimulyo, Nanggulan, Kalibawang, and Samigaluh Subdistrict, are frequently subjected to land slide and erosion. Beside having high land slide risk, It also has high and intermediate water overflow risk [4]. Main driving factors that lead to land slide in Kulon Progo are high rainfall rate, mining activity, and land function conversion. Subdistricts that often experienced land slide are Samigaluh [5]. Beside rainfall factor, other factors such as mountainous terrain, illegal logging, and forest with steep slope angle misfunctioned into farm fields also become factors that lead to land slide.

Land function conversion is defined as increasing number of land use from one type use to another type followed by decreasing number of one type from time to time or change of 
function of land at different times [6]. Accorfng to Koomen and Stillwell in [7], land use conversion is a procesa of transformation or alocation. [8] states that process is a sequence of steps from an event to another event that develop into something else. Related into land function conversion, that process means sequence of events of land function change or change of land use from initial function to another function.

According [9] for a guide of urban space management and control, urban planology plays vital role in enviromental conservation. Thus, urban planning have to be conducted by taking consideration of environmental aspect propotionally beside physic, social, economy, and security aspects.

This study will give a depiction of land conversion by the community in Samigaluh and Kalibawang Subdistricts. Other than that, this study will also analyze the difference between land use conversion in Samigaluh Subdistrict and Kalibawang Subdistrict. Output of this study can give goverment, as well as community, an illustration of land use conversion dispersion which can be associated to land slide occurence in both subdistricts.

\section{Methods}

Study of land function determination by slope and geological aspects carried out in some finite steps. Research flowchart can be seen at Figure 1.

Aim of the research is to compare land function conversion over Samigaluh and KalibawangSubdistrict. Four steps are carried out. First, investigation of geomorphological properties such as land slope, rainfall, and soil type over both subdistricts. Second, overlain values ofgeomorphological parametersobtained from first step result in land function divisions. Third, site observation of actual land use in the community. And the fourth, comparation of land function from geomorphological aspects with the actual use.

Sample size in this research is 128 and 25 observation points in Samigaluh and Kalibawang Subdistrict respectively.The difference of sample size is regard to different value of subdistricts area, which the later subdistrict is smaller in area.

The analysis is divided into two parts. First part is a descriptive analysis with a purpose of characterizing the conformity between the geomorphological aspects and the actual use. The second part is aninference analysis with purpose of comparatively testing the hypothesis (Man Witney Test). 


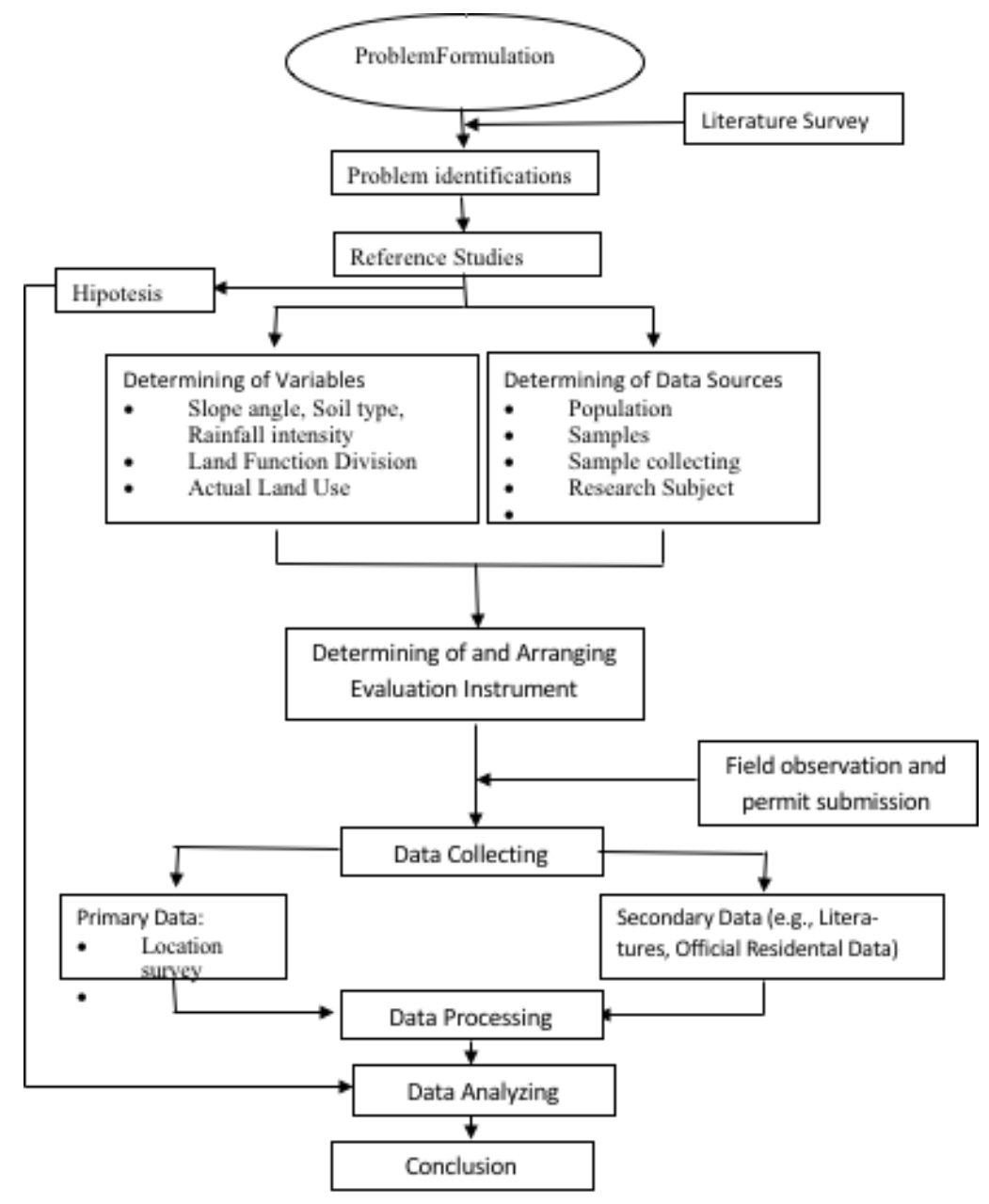

Fig. 1. Research Flowchart

\section{Results and Discussion}

\subsection{Land Function Division and Actual use of Land Area in Samigaluh Subdistrict}

Land function determination criteria has three variables, i.e., land slope, soil type with regard to erosion, and rainfall intensity. Each of these variables are obtained from topographic map, geological map, and daily average rainfall intensity data respectively and are plotted and overlain on a map.Converting the quality of each parameters into score numbers and summing its values result in a map of land function classification.

Result of the three geomorphological parameters analysis yields four regions of land function, i.e., protected area, which is filled in red color in the map, support area, filled in blue, annual crop cultivation area, filled in yellow, and seasonal crop cultivation area, filled in green.

Actual land use in Samigaluh subdistrict are observed in 128 dispersed locations.For example. Figure 2 shows overlain maps of slope, rainfall, and soil type in Banjarsari Village 
that can be seen in colored area of respective land use type. On the same map, observed actual land uses on those 128 points are also plotted. Overall result of actual land use observation in Samigaluh district isdescribed in Table 1.

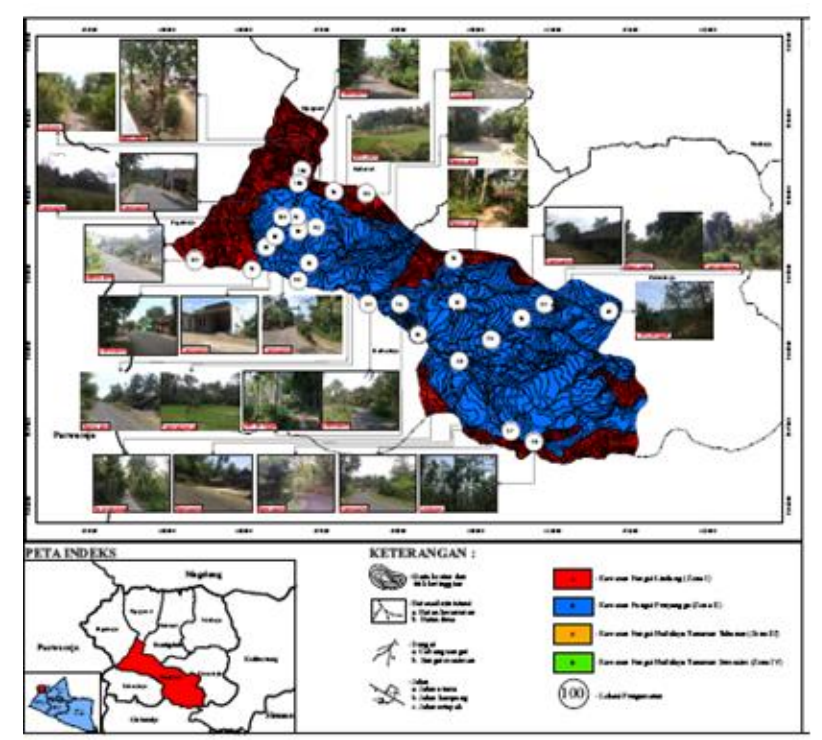

Fig. 2. Land Function Division Map of Banjarsari Village, Samigaluh, KulonProgo

Tabel 1. Land Use Conformity Description between Geomorphological Aspects and Actual Use in Samigaluh Subdistrict, Kulon Progo (Source: processed primary data, 2018)

\begin{tabular}{|l|l|l|c|}
\hline No & Cathegory & Frequency & Percentage (\%) \\
\hline 1 & $\begin{array}{l}\text { Observed land uses conform with } \\
\text { geomorphological land function division }\end{array}$ & 67 & 52.34 \\
\hline 2 & $\begin{array}{l}\text { Observed land uses unconform with } \\
\text { geomorphological land function division }\end{array}$ & 61 & 47.66 \\
\hline & \begin{tabular}{l} 
Total \\
\hline
\end{tabular} \\
\hline
\end{tabular}

Based on above data, from 128 observation locations, 67 (52,34\%) locations are conforms between the determined land function and actual use by the residents in Samigaluh Subdistrict. The other $61(47,66 \%)$ locations are observed unconform.

\subsection{Land Function Division and Actual use of Land Area in Kalibawang Subdistrict}

Actual land use in Kalibawang Subdistrict is observed at 25 locations. Division of Land Use in Kalibawang Subdistrict is shown at Figure 3. Overall result of actual land use observation in Kalibawang district is described in Table 2. 


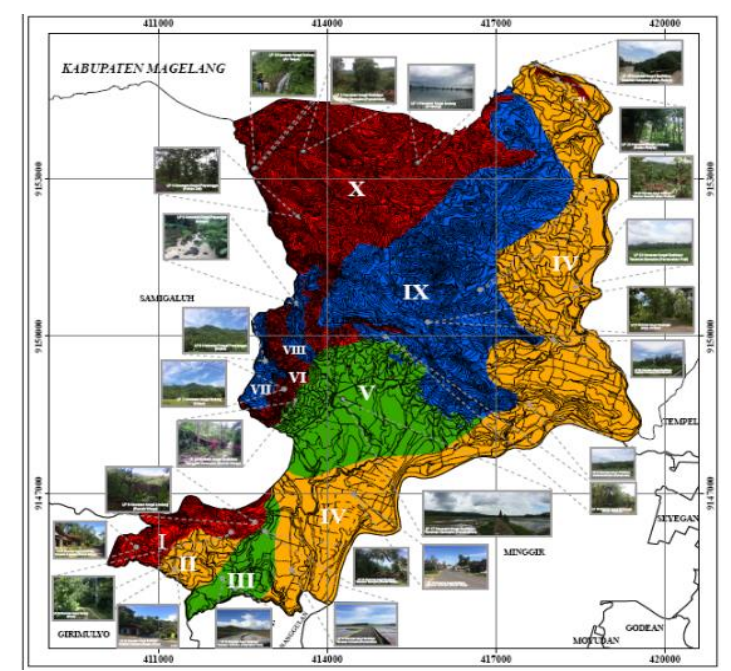

Fig. 2. Map describes Land Function Division and Actual Land Usein Kalibawang Subdistrict, Kulo Progo

Table 2. Land Use Conformity Description between Geomorphological Aspects and Actual Use in Kalibawang Subdistrict, Kulon Progo (Source: processed primary data, 2018)

\begin{tabular}{|c|l|c|c|}
\hline No & \multicolumn{1}{|c|}{ Cathegory } & Frequency & Percentage (\%) \\
\hline 1 & $\begin{array}{l}\text { Observed land uses conform with } \\
\text { geomorphological land function division }\end{array}$ & 18 & 72 \\
\hline 2 & $\begin{array}{l}\text { Observed land uses unconform with } \\
\text { geomorphological land function division }\end{array}$ & 7 & 28 \\
\hline & Total & 25 & 100 \\
\hline
\end{tabular}

Based on above data, from 25 observation locations, 18 (72\%) locations are conforms between the determined land function and actual use by the residents in Kalibawang Subdistrict. The other 7 (28\%) locations are observed unconform.

\subsection{Analisis Data}

Comparative analysis land function conversion in Samigaluh and Kalibawang Subdistricts using non parametric test, i.e., Man Witney test. Result of this test is shown in Table 3.

Tabel 3. Man Withey Test Result (Source: Processed Primary Data)

\begin{tabular}{|c|c|c|c|c|}
\hline Variables & Mean Rank & Zcalculation & Significancy & Conclusion \\
\hline $\begin{array}{l}\text { Conversed Land Uses in } \\
\text { Samigaluh Subdistrict }\end{array}$ & 79.86 & \multirow{2}{*}{-2.001} & \multirow{2}{*}{0.045} & \multirow[t]{2}{*}{$\mathrm{HO}$ is false } \\
\hline $\begin{array}{l}\text { Conversed Land Uses in } \\
\text { Kalibawang Subdistrict }\end{array}$ & 62.38 & & & \\
\hline
\end{tabular}

From statistics $\mathrm{Z}$ test, it is obtained that the $\mathrm{Z}$ value is -2.001 while the 2-tailed sigificancy is 0.045 . Proposed hipotheses in this research are: 
Ho : There are no differences between geomorphological land function with actual land use in the community

$\mathrm{Ha}$ : There is a difference between geomorphological land function division with actual land use in the community

The calcuated $\mathrm{z}$ value from difference of the variables is compared to $\mathrm{z}$ value in the statristics $z$ value table. Wth $95 \%$ certainty level of 2 -tailed test, $z$ table value is \pm 1.96 . This makes calculated $\mathrm{z}$ value of -2.001 lies in the range for rejecting Ho (zcalculation $<-1,96$ ). Besides, by comparing probability value, based on Table 3, Significancy shows value of 0.045 which is smaller than 0.05. Thus, Ho is false. This concludes that Ho is rejected or Ha is true, in other words, there are diifferences between geomorphological land function division with actual land use in the community in Samigaluh and Kalibawang Subdistricts in Kulon Progo.

\section{Conclusion}

With $47.66 \%$ of locations in Samigaluh Subdistric and $28 \%$ of location in Kalibawang Subdistric are observed unconform, there are differences between geomorphological land function division with actual land use in the community in each of Samigaluh and Kalibawang Subdistricts.

\section{References}

[1] Aris Dwi. W. 2010. Land Slide Susceptibility Level at Residential Location in Gedangsari Subdistrict, Gunung Kidul. Final Project. Yogyakarta : Faculty of Geogtlraphy UGM.

[2] Badan Perencanaan Pembangunan Daerah-BPS Kota Yogyakarta. 2016. Statistic Information Analysis of Local Development 2016.

[3] BNPB. 2016. Monthly Up to Date Disaster Information November 2016.

[4] DIY Goverment. 2010. Regulation of Special Region of Yogyakarta No. 8 Years 2010 about Disaster Mitigation

[5] BPS Kulon Progilo District, 2018. Statistic of Kulonprogo District 2018. PT. Solo Grafika Utama

[6] Wahyunto, M.Z. Abidin., A. Priyono and Sunaryanto. 2001. Study of Land Use Conversion Citarik DAS, West Java and Garang DAS, East Java. National Seminat Article Farm Field Multifunction, ASEAN Secretariate Maff Japan \& Soil and Agroclimate Research and Development Center. Bogor.

[7] Krisnaningtyas, Tessie, and Endang Trimarmanti, 2014. Regional and Enviromental Journal : Land Use Conversion Evaluation at Cisadane River's Flowline Area, Bogor District. Spatial Planning Directorate General, Ministry of Public Work Jakarta, Indonesia.

[8] Yunus, Hadi Sabari, 2001. Land Utility Conversion at Countryside Area (City of Yogyakarta Countryside Case). Dissertation. Faculty of Geography Gajah Mada University. Yogyakarta : UGM

[9] Yunianto, Ardi Chandra. 2011. Analysis of Landslide Vulnerability with Geographic Information System (GIS) and Remote Sensing Application in Bogor Regency. Institut Pertanian Bogor 